\title{
Detection of Helicobacter pylori in Various Types of Vegetables and Salads
}

\author{
Shahrzad Atapoor ${ }^{1}$; Farhad Safarpoor Dehkordi ${ }^{2}$; Ebrahim Rahimi ${ }^{3,}$ \\ ${ }^{1}$ Faculty of Agriculture and Natural Sciences, Shahrekord Branch, Islamic Azad University, Shahrekord, IR Iran \\ ${ }_{2}$ Faculty of Agriculture and Natural Sciences, Shahrekord Branch, Islamic Azad University, Shahrekord,
2 Young Researchers and Elites Club, Shahrekord Branch, Islamic Azad University, Shahrekord, IR Iran \\ 3 Young Researchers and Elites Club, Shahrekord Branch, Islamic Azad University, Shahrekord, IR Iran
Department of Food Hygiene and Public Health, College of Veterinary Medicine, Shahrekord Branch, Islamic Azad University, Shahrekord, IR Iran \\ ${ }^{*}$ Corresponding author: Ebrahim Rahimi, Department of Food Hygiene and Public Health, College of Veterinary Medicine, Shahrekord Branch, Islamic Azad University, Shahrekord, \\ IR Iran. Tel: +98-9133278377, Fax:+98-3813361060, E-mail: ebrahimrahimi55@yahoo.com \\ Received: December 28, 2012; Revised: April 25, 2013; Accepted: June 1, 2013
}

\begin{abstract}
Background: There is a possibility for the presence of Helicobacter pylori in vegetables due to their close contact with polluted water, soil and feces.

Objectives: This study was carried out to detect the presence of $H$. pylori in vegetables and salads in Iran.

Materials and Methods: In total, 460 vegetable and salad samples were collected and transferred immediately to the laboratory. All samples were cultured and tested for the presence of H. pylori using the Polymerase Chain Reaction technique.

Results: The results showed that 44 of 460 samples (9.56\%) were positive for $H$. pylori using the culture method. The Polymerase Chain Reaction technique showed that 50 of 460 samples (10.86\%) were positive for H. pylori. Un-washed leek, traditional salad, un-washed basil and un-washed lettuce were the most commonly contaminated samples. The presence of the bacteria in various vegetables was statistically significant $(\mathrm{P}<0.05)$.

Conclusions: Vegetables are a new source of H.pylori and accurate washing of vegetables improves such contaminations.
\end{abstract}

Keywords:Helicobacter pylori; Vegetables; Culture; Polymerase Chain Reaction

\section{Background}

Vegetables and salads are rich and comparatively cheaper source of vitamins. Consumption of these food sources provides taste, palatability, increases appetite and provides fiber for digestion and prevents constipation. Vegetables are in contact with soil, polluted water, animal manure and even stool. Therefore, they can easily become contaminated. A previous study showed that soil, water, animal manure and stool (1) are the main sources of $\mathrm{He}$ licobacter pylori. H. pylori is a microaerophilic Gram negative bacteria with a curved spiral shape which is known as a causative agent of type B gastritis, peptic ulcer disease, gastric adenocarcinoma and mucosa associated lymphoid tissue lymphoma (2). The bacteria has been classified as a Class I carcinogen by the World Health Organization (3). The prevalence of infection is typically higher in developing countries (> 80\%) and lower in developed nations $(<40 \%)$ with a declining pattern worldwide $(4,5)$. Prescription of antibiotics is the main protocol for treatment of diseases caused by H. pylori (6). However, antibiotic therapy fails in about $20 \%$ of the patients (5), mainly due to antibiotic resistance (7). During the last two decades, the role of $H$. pylori as a potential pathogen in both human and veterinary medicine has been investigated intensively and evidence suggests possible zoo- notic transmission of animal helicobacters to humans.

\section{Objectives}

The epidemiology and prevalence of $H$. pylori in food sources, especially vegetables and salads, is essentially unknown. Therefore, the present study was carried out in order to detect $H$. pylori in various types of traditional, commercial, washed and un-washed vegetables and salads in Iran.

\section{Materials and Methods}

\subsection{Samples and Isolation of H. pylori}

A total of 460 vegetable and salad samples were collected from supermarkets and groceries of various parts of Iran (Table 1). The samples were processed within an hour of collection. Samples were homogenized and $25 \mathrm{~mL}$ of each sample was added to $225 \mathrm{~mL}$ of Columbia blood agar (Oxoid, UK) supplemented with 5\% horse serum (Sigma, St. Louis, MO, USA) and colistinme than esulfonate (30 $\mathrm{mg} / \mathrm{L})$, cycloheximide (100 mg/L), nalidixic acid (30 mg/L), trimethoprim (30 mg/L), and vancomycin (10 mg/L) (Sigma, St. Louis, MO, USA) and incubated for seven days at $37^{\circ} \mathrm{C}$ with constant shaking under microaerophilic con 
Table 1. Distribution of H. pylori in Commercial and Traditional Salads and Washed and Un-washed Vegetables Using Culture and PCR Techniques ${ }^{\mathrm{a}}$

\begin{tabular}{|c|c|c|c|}
\hline Type of Samples & Number of Samples & Positive Culture & Positive PCR \\
\hline \multicolumn{4}{|l|}{ Salad } \\
\hline Commercial & 30 & $1(3.33)$ & $1(3.33)$ \\
\hline Traditional & 30 & $7(23.33)$ & $9(30)$ \\
\hline \multicolumn{4}{|l|}{ Basil } \\
\hline Washed & 20 & - & - \\
\hline Un-washed & 20 & $4(20)$ & $5(25)$ \\
\hline \multicolumn{4}{|l|}{ Radish } \\
\hline Washed & 20 & - & - \\
\hline Un-washed & 20 & $3(15)$ & $3(15)$ \\
\hline \multicolumn{4}{|l|}{ Leek } \\
\hline Washed & 20 & $1(5)$ & $1(5)$ \\
\hline Un-washed & 20 & $6(30)$ & $7(35)$ \\
\hline \multicolumn{4}{|l|}{ Spinach } \\
\hline Washed & 40 & $1(2.5)$ & $1(2.5)$ \\
\hline Un-washed & 40 & $4(10)$ & $4(10)$ \\
\hline \multicolumn{4}{|l|}{ Lettuce } \\
\hline Washed & 40 & $3(7.5)$ & $3(7.5)$ \\
\hline Un-washed & 40 & $7(17.5)$ & $8(20)$ \\
\hline \multicolumn{4}{|l|}{ Parsley } \\
\hline Commercial & 40 & $1(2.5)$ & $1(2.5)$ \\
\hline Washed & 40 & $2(5)$ & $2(5)$ \\
\hline Un-washed & 40 & $4(10)$ & $5(12.5)$ \\
\hline Total & 460 & $44(9.56)$ & $50(10.86)$ \\
\hline
\end{tabular}

a Data are presented in NO.(\%).

ditions. Next, $0.1 \mathrm{~mL}$ of the enrichment selective broth was plated onto Columbia blood agar (Oxoid, UK) supplemented with $5 \%$ of defibrinated horse blood and $30 \mathrm{mg} / \mathrm{L}$ colistinmethanesulfonate, $100 \mathrm{mg} / \mathrm{L}$ cycloheximide, 30 $\mathrm{mg} / \mathrm{L}$ nalidixic acid, $30 \mathrm{mg} / \mathrm{L}$ trimethoprim, and $10 \mathrm{mg} / \mathrm{L}$ vancomycin (Sigma, St. Louis, MO, USA) (8) and incubated for seven days at $37^{\circ} \mathrm{C}$ under microaerophilic conditions. Suspected colonies were identified as H. pylori based on the method described by Dunn et al. (9). For comparison, a reference strain of H. pylori (ATCC 43504) was employed. The isolates were confirmed using the PCR assay.

\subsection{DNA Extraction and PCR Amplification}

DNA from $1 \mathrm{~mL}$ of each vegetable and salad sample was extracted by a DNA isolation kit for cells and tissues (Roche Applied Science, Germany, 11814770001), according to the manufacturer's instructions. Extracted genomic DNA was amplified for the ureC gene and detected with specific primers HP-F: 5'-GAATAAGCTTTTAGGGGTGTTAGGGG-3', HP-R: 5'GCTTACTTTCTAACACTAACGCGC-3'. The gene product was $294 \mathrm{bp}$. The PCR conditions and temperatures were based on the Rahimi and Kheirabadi protocol (10). Samples inoculated with H. pylori were used as positive controls.

\subsection{Statistical Analysis}

Data were transferred to Microsoft Excel spreadsheet (Microsoft Corp., Redmond, WA, USA) for analysis. Using SPSS 16.0 statistical software (SPSS Inc., Chicago, IL, USA), Chi-square test and Fisher's exact two-tailed test analysis were performed and differences were considered significant with $\mathrm{P}<0.05$.

\section{Results}

Table 1 presents the distribution of $H$. pylori isolated from various types of vegetable and salad samples in Iran. In this study, 44 of 460 samples (9.56\%) were found to be contaminated with $\mathrm{H}$. pylori using the culture method (Figure 1). There were significant differences $(\mathrm{P}<0.05)$ between the prevalence rates of $H$. pylori in commercial 


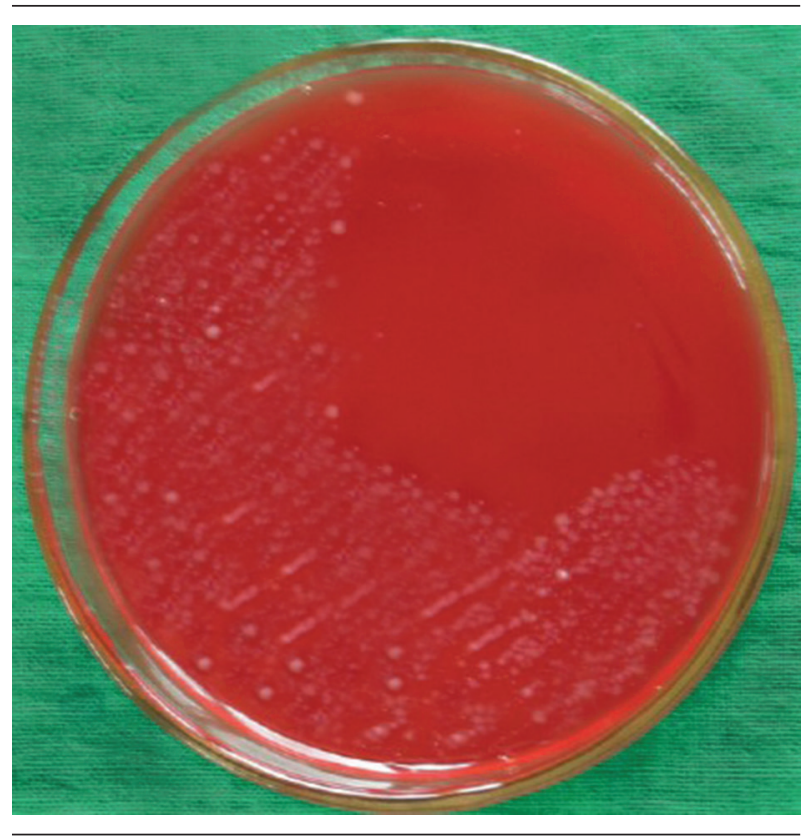

Figure 1. The colonies of H. pylori on Columbia Blood Agar Medium

and traditional salads as well as between washed and un-washed vegetables. The PCR technique showed that 50 of 460 samples $(10.86 \%)$ were contaminated with $H$. pylori (Table 1). No significant differences were observed between the abilities of culture and PCR techniques for detection of $H$. pylori in vegetable and salad samples. The most commonly contaminated vegetables were unwashed leek (35\%), followed by un-washed basil (25\%) and un-washed lettuce (20\%).

\section{Discussion}

Several studies have addressed the role of food in the transmission of $H$. pylori $(10,11)$. Moreover, nowadays there is an increasing demand for minimally processed vegetables packed under a modified atmosphere (12). Several studies have confirmed the high presence of $H$. pylori in pasteurized and sterilized food products $(13,14)$. Therefore, emphasis on hygiene can be an exceptional way for reducing the load of $H$. pylori in foods. Food products that have been analyzed thus far mainly include milk, meat and vegetables. Among these, milk products are the most studied while vegetables are rare (14).

Rahimi and Kheirabadi (10) reported that the H. pylori ure $C$ gene was detected in 56 of 448 (12.5\%) Iranian milk samples, including 19 cows (14.1\%), 11 sheep (12.2\%), nine goats (8.7\%), two camels (3.6\%) and 15 buffalo (23.4\%) milk samples. However, it has been described that individuals who consume vegetables are more likely to acquire $H$. pylori (15). Also, the isolation of $H$. pylori is not always associated with raw milk. For instance a study on 440 raw sheep milk samples did not yield any $H$. pylori isolates (16). Besides, H. pylori can survive for short periods in milk (17).

The association of the infection with consumption of raw vegetables is an additional indirect evidence for the presence of $H$. pylori in water used for irrigation of these vegetables $(17,18)$. A previous study indicated that poor quality water could represent an important vehicle for $H$. pylori transmission (19). In addition to water used for irrigation of vegetables, animal manure used for reinforcement of soil is an additional indirect evidence for the presence of $H$. pylori in vegetables. This bacteria has been isolated previously from cow's fecal samples (20). Feces of animal and especially cows have been used for reinforced agricultural soil. Fujimura et al. (13) showed that the prevalence of $H$. pylori was $50 \%$ in cow feces and $38 \%$ in soil samples. Also, this bacteria has been isolated from various animal sources (21). Contact with cow feces is one of the main sources of vegetable contamination.

Another previous study showed that $H$. pylori survived for 72 hours in sanitized and up to 96 hours in sterilized vegetables $(22,23)$. Foods with water activity higher than 0.97 and $\mathrm{pH}$ ranging from 4.9 to 6.0 theoretically provide conditions for the survival of $H$. pylori. Also, the general lack of efficient sanitation in removing or killing pathogens on raw fruits and vegetables may contribute to harbor pathogens (12). H. pylori is unlikely to grow on most food products, but it is able to survive in a low acid and high moisture environment for extended periods of time, especially if refrigerated. As far as we know, vegetables grow in high moisture soil, which can allow $H$. pylori development for a long duration of time.

This is the first paper to report on the contamination of basil, spinach, salad, parsley, leek and radish by $H$. pylori in Iran. Proof of the ability of $H$. pylori to survive in common foods supports the hypothesis that primary contamination of a food product (animal reservoir) or secondary contamination due to inappropriate handling (human reservoir) can be a vehicle for H. pylori transmission. Polluted water, feces, animal manure and even soil are the main resources for contamination of vegetables with $H$. pylori. The results of this study showed that $H$. pylori have a higher presence in un-washed vegetables and traditional salads. Therefore, pasteurization, sterilization and accurate washing can reduce the microbial load of vegetables.

\section{Acknowledgements}

The authors would like to thank Dr. A. Shakerian and Dr. M. Ameri for their important technical and clinical support.

\section{Authors' Contribution}

SHA carried out the sampling and culture method. FSD carried out the molecular genetic studies, participated in the primers sequence alignment, writing and drafted the manuscript. ER participated in the design of the study, performed the statistical analysis and managed the project. All authors read and approved the final manuscript. 


\section{Financial Disclosure}

Authors declare that they have no conflict of Interest.

\section{Funding/Support}

Financial support of this study was provided by the authors.

\section{References}

1. Sasaki K, Tajiri Y, Sata M, Fujii Y, Matsubara F, Zhao M, et al. Helicobacter pylori in the natural environment. Scand J Infect Dis. 1999;31(3):275-9.

2. Hegarty JP, Dowd MT, Baker KH. Occurrence of Helicobacter pylori in surface water in the United States. J Appl Microbiol. 1999;87(5):697-701.

3. Aruin LI. [Helicobacter pylori infection is carcinogenic for humans].Arkh Patol.1997;59(3):74-8.

4. Perez-Perez GI, Rothenbacher D, Brenner H. Epidemiology of Helicobacter pylori infection. Helicobacter. 2004;9 Suppl 1:1-6.

5. Kusters JG, van Vliet AH, Kuipers EJ. Pathogenesis of Helicobacter pylori infection. Clin Microbiol Rev. 2006;19(3):449-90.

6. Parente F, Cucino C, Bianchi Porro G. Treatment options for patients with Helicobacter pylori infection resistant to one or more eradication attempts. Dig Liver Dis. 2003;35(8):523-8.

7. Megraud F. H pylori antibiotic resistance: prevalence, importance, and advances in testing. Gut. 2004;53(9):1374-84.

8. Poms RE, Tatini SR. Survival of Helicobacter pylori in ready-to-eat foods at 4 degrees C. Int J Food Microbiol. 2001;63(3):281-6.

9. Dunn BE, Cohen H, Blaser MJ. Helicobacter pylori. Clin Microbiol Rev. 1997;10(4):720-41.

10. Rahimi E, Kheirabadi EK. Detection of Helicobacter pylori in bovine, buffalo, camel, ovine, and caprine milk in Iran. Foodborne Pathog Dis. 2012;9(5):453-6.

11. Meng X, Zhang H, Law J, Tsang R, Tsang T. Detection of Helicobacter Pylori from Food Sources by a Novel Multiplex PCR Assay.J Food Saf. 2008;28(4):609-19.
12. Beuchat LR. Ecological factors influencing survival and growth of human pathogens on raw fruits and vegetables. Microbes Infect. 2002;4(4):413-23.

13. Fujimura S, Kawamura T, Kato S, Tateno H, Watanabe A. Detection of Helicobacter pylori in cow's milk. Lett Appl Microbiol. 2002;35(6):504-7.

14. Vale FF, Vitor JM. Transmission pathway of Helicobacter pylori: does food play a role in rural and urban areas? Int J Food Microbiol. 2010;138(1-2):1-12.

15. Chen SY, Liu TS, Fan XM, Dong L, Fang GT, Tu CT, et al. [Epidemiological study of Helicobacter pylori infection and its risk factors in Shanghai]. Zhonghua Yi Xue Za Zhi. 2005;85(12):802-6.

16. Turutoglu $\mathrm{H}$, Mudul S. Investigation of Helicobacter pylori in raw sheep milk samples. J Vet Med B Infect Dis Vet Public Health. 2002;49(6):308-9.

17. Quaglia NC, Dambrosio A, Normanno G, Celano GV. Evaluation of a Nested-PCR assay based on the phosphoglucosamine mutase gene $(\mathrm{glmM})$ for the detection of Helicobacter pylori from raw milk. Food Control. 2009;20(2):119-23.

18. Mazari-Hiriart M, Lopez-Vidal Y, Castillo-Rojas G, Ponce de Leon S, Cravioto A. Helicobacter pylori and other enteric bacteria in freshwater environments in Mexico City. Arch Med Res. 2001;32(5):458-67.

19. Mazari-Hiriart M, Ponce-de-Leon S, Lopez-Vidal Y, Islas-Macias P Amieva-Fernandez RI, Quinones-Falconi F. Microbiological implications of periurban agriculture and water reuse in Mexico City PLoS One. 2008;3(5).

20. Safaei HG, Rahimi E, Zandi A, Rashidipour A. Helicobacter pylori as a zoonotic infection: the detection of $\mathrm{H}$. pylori antigens in the milk and faeces of cows. J Res Med Sci. 2011;16(2):184-7.

21. Tabatabaei M. Application of Molecular and Cultural Methods for Identification of Helicobacter spp. In Different Animal Sources. Glob Vet. 2012;8(3):292-7.

22. Park SR, Mackay WG, Reid DC. Helicobacter sp. recovered from drinking water biofilm sampled from a water distribution system. Water Res. 2001;35(6):1624-6.

23. Gomes BC, De Martinis ECP. Fate of Helicobacter pylori artificially inoculated in lettuce and carrot samples. Braz J Microbiol. 2004;35(1-2):145-50. 